\title{
Carbon dioxide concentration in air within the Nerja Cave (Malaga, Andalusia, Spain)
}

\author{
Cristina Liñán ${ }^{1,2}$, Iñaki Vadillo ${ }^{2}$ and Francisco Carrasco ${ }^{2}$
}

\begin{abstract}
:
Liñán C., Vadillo I. and Carrasco F. 2008. Carbon dioxide concentration in air within the Nerja Cave (Malaga, Andalusia, Spain). International Journal of Speleology, 37 (2), 99-106. Bologna (Italy). ISSN 0392-6672.

From 2001 to 2005 the $\mathrm{CO}_{2}$ concentration of the air in the interior and exterior of the Nerja Cave was studied and its relation with the air temperature and visitor number. The average annual $\mathrm{CO}_{2}$ concentration outside of the cave is 320 ppmv, whilst inside, the mean concentration increases to $525 \mathrm{ppmv}$ during autumn and winter, and in the order of $750 \mathrm{ppmv}$ during spring and summer. The temporal variation of $\mathrm{CO}_{2}$ content in the air of the cave is strongly influenced by its degree of natural ventilation which is, in turn, determined by the difference between external and internal air temperatures. During autumn, winter and spring, a positive correlation between the $\mathrm{CO}_{2}$ content of the air inside the cave and the temperature difference between the external and internal air was observed, such that when this difference increased, there was a higher level of $\mathrm{CO}_{2}$ within the cave. Then, the ventilation is high and $\mathrm{CO}_{2}$ levels are mainly of human origin. During summer, there was a negative correlation between $\mathrm{CO}_{2}$ and the temperature difference between the air outside and that inside the cave: when the temperature difference increases, the $\mathrm{CO}_{2}$ content within the cave is lower. At this time of the year, the renovation of the air is much slower due to the lower ventilation. A positive correlation between $\mathrm{CO}_{2}$ concentration of the air in the cave and the visitor number can only be observed during August, the month that receives the most visits throughout the year averaging 100,000 .
\end{abstract}

Keywords: carbon dioxide, Nerja Cave, air temperature, visitor number, cave ventilation.

Received 9 November 2006; Revised 4 December 2007; Accepted 13 December 2007

\section{INTRODUCTION}

In caves adapted for tourism, the control of carbon dioxide levels is crucial for the cave's conservation as well as for public health, so that an adequate air quality is maintained for the visitors. On one hand, the $\mathrm{CO}_{2}$ concentration in the air in karstic caves conditions the development of different speleogenetic processes within these caves given that it directly influences the precipitation/dissolution of carbonates (White, 1988, 1997; Dreybrodt, 2000; Dreybodt \& Eisenlohr, 2000). On the other hand, the $\mathrm{CO}_{2}$ concentration determines the cave's air quality, as elevated $\mathrm{CO}_{2}$ concentrations above 5000 ppmv are noxious to human health (Halbert, 1982).

Numerous authors have studied $\mathrm{CO}_{2}$ from diverse standpoints. Pioneering studies have been made on the presence and dynamics of $\mathrm{CO}_{2}$ in caves with respect to the exterior environment, for example Renault (1968), Ek (1968, 1979, 1981), James (1977) and Troester \& White (1984). Other authors

1 Nerja Cave Research Institute, Nerja Cave Foundation, Carretera de Maro s/n, 29787-Nerja (Málaga). cbaena@ cuevanerja.com

2 Hydrogeology Group, Science Faculty. Universidad de Málaga.29787- Málaga.vadillo@uma.es, fcarrasco@uma.es have focused on studying the spatial and/or temporal distribution of $\mathrm{CO}_{2}$ (Atkinson, 1977; Wood \& Petraitis, 1984; Wood, 1985), or the dynamics within the caves (Ek \& Gewelt, 1985; Bourges et al., 2001; Batiot, 2002; Baldini et al., 2006; Batiot et al., 2006). The human impact on tourist caves, using $\mathrm{CO}_{2}$ content as one of the reference parameters, is another research line that has been widely developed in recent decades (Villar et al., 1986; Dragovich \& Grose, 1990; Craven, 1996; Hoyos et al., 1998; De Freitas \& Banbury, 1999, Liang et al., 2000; Carrasco et al., 2002; Zelinka, 2002). Other interesting recent references dealing with $\mathrm{CO}_{2}$ are: Spötl et al., 2005; Denis et al., 2005; Faimon et al., 2006 ; Bourges et al., 2006; Fernández-Cortés et al., 2006 and BatiotGuilhe et al., 2007.

\section{CHARACTERISTICS OF THE STUDY AREA}

The Nerja Cave is located in Andalusia (southern Spain), in the province of Malaga, about $5 \mathrm{~km}$ east of the coastal town Nerja. The climate outside the cave is typically Mediterranean, with a wet season from October to February and a long dry season that is especially notable during the summer. The mean annual values for rainfall and temperature are 490 $\mathrm{mm}$ and $18.8^{\circ} \mathrm{C}$ respectively. 
From the geological viewpoint, the Nerja Cave is situated on the southern border of Sierra Almijara, within the Alpujarride Complex of the Betic Cordillera. It is developed within a highly fractured medium and coarse-grained dolomite marbles, from the Middle Triassic (Fig. 1A). The marbles are permeable due to fracturing and karstification and, thus, constitute a carbonate aquifer. As a result of the Plio-Quaternary tectonic activity which affected this area, the cave is currently located in the unsaturated zone of the aquifer, above the piezometric level. The thickness of the unsaturated zone above the cave is highly variable, from 4 to $50 \mathrm{~m}$ in the external part, while in the internal area it exceeds $90 \mathrm{~m}$. Except for the gardens near the entrance, only low shrubs or soil are found above the cave.The cave has three entrance points, two of them are sinkholes (at 161 and 162 m.a.s.1.) and the third is a wider entrance which is equipped for tourist visits, found at 158 m.a.s.l. The cave extends almost horizontally between limits of 123 and 191 m.a.s.1. and occupies a volume of about $300,000 \mathrm{~m}^{3}$, a third of which is prepared to receive tourist visits (Figs. 1B y 1C). The Nerja Cave is one of the most visited natural sites in Andalusia (Carrasco et al., 1999), receiving an average of 500,000 visitors yearly.

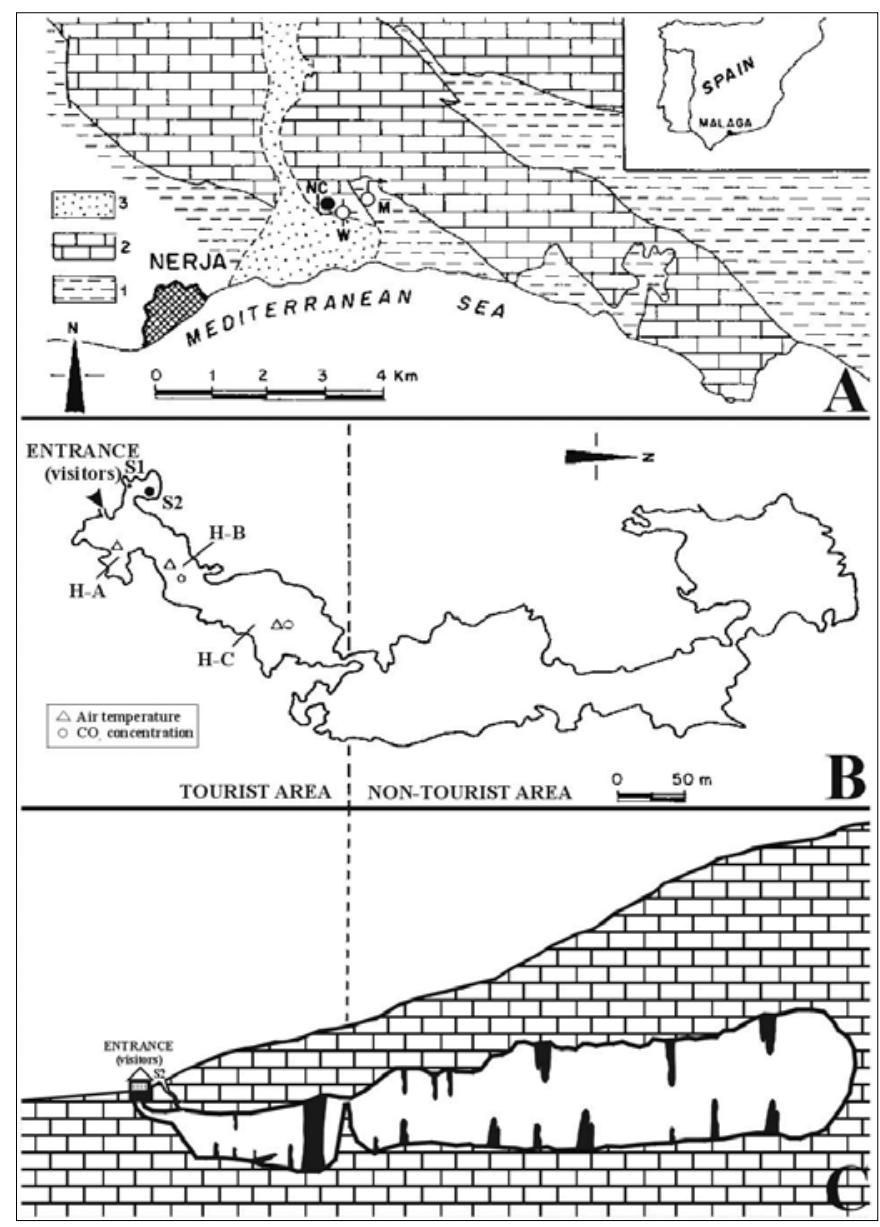

Fig. 1. Situation and geological sketch of the Nerja Cave (modified from Carrasco et al., 1995). A: 1, metapelites; 2, carbonates; 3 , Pliocene and Quaternary deposits; NC, cave entrance; M, Maro spring; W, cave well. B: location of the sensors in the cave. H-A: Hall of the Nativity, H-B: Hall of the Cascade, H-C: Hall of the Cataclysm, S1 and S2: natural entrances (sinkholes). C: cross-sectional sketch (not to scale) of the Nerja Cave.
Since 1993, the tourist galleries inside the cave have been fitted with a complete network for specialised monitoring (Liñán et al., 2004) that makes the continuous monitoring (at an hourly rate) of the most significant environmental parameters within the cave possible, such as the temperature, relative humidity and concentration of $\mathrm{CO}_{2}$ in the air, and also to evaluate the human influence on the subterranean microclimate.

Previous research carried out in the Nerja Cave (Carrasco et al., 1999, 2002; Liñán et al., 2000; Liñán et al., 2004) examined the mean daily concentrations of $\mathrm{CO}_{2}$ in the tourist galleries and analysed their spatial and temporal variations with respect to the visitor number, the natural ventilation within the cave (Cañete, 1997; Dueñas et al., 1999), the greater or lesser dripwater volume and the dimensions of the galleries (Benavente et al., 2005). The present paper presents an analysis of the concentration of $\mathrm{CO}_{2}$ in the exterior and the interior of the cave during the years 2001 to 2005 and its relation with other parameters measured inside and outside the cave. In particular, the authors seek to provide new data on the close relation between the $\mathrm{CO}_{2}$ content within the cave and the air temperature, as well as the significant effects of the natural ventilation of the cave.

\section{METHODOLOGY}

Commercial OLLARTE sensors were used to measure the exterior and interior temperatures and the $\mathrm{CO}_{2}$ content within the cave. The $\mathrm{CO}_{2}$ sensor employed an infrared non-dispersive measuring technique. Its working range was from 0 to 3,000 ppmv with a resolution of 1 ppmv. The temperature was measured using sensors fitted with a platinum thread sensor element, with a variation range of 0 to $40{ }^{\circ} \mathrm{C}$ and a resolution of $0.05^{\circ} \mathrm{C}$.

To measure the $\mathrm{CO}_{2}$ content of the air outside the cave, a TESTO commercial sensor was used. This employed the infrared non-dispersive technique to obtain readings, and had a measurement range of $0-10,000 \mathrm{ppmv}$, a resolution of $1 \mathrm{ppmv}$ and an accuracy of $\pm 50 \mathrm{ppmv} \pm 2 \%$ of the volume measured.

\section{RESULTS AND DATA ANALYSIS}

Outside the Nerja Cave, the mean concentration of $\mathrm{CO}_{2}$ in the air was found to be $318 \pm 21 \mathrm{ppmv}$ (Fig. 2). Minimum values were recorded during the summer (from June to September) and maximum values corresponded to the winter and spring (from December to April).

In the autumn, winter and spring, the mean monthly concentration of $\mathrm{CO}_{2}$ outside the cave is fairly constant, between 340 and 320 ppmv, while in the summer it is somewhat lower, at around 290 ppmv. Minimum and maximum mean monthly values were recorded in August (288 \pm 29 ppmv) and March (347 \pm 14 ppmv), respectively.

Inside the Nerja Cave, the concentration of $\mathrm{CO}_{2}$ in the air varies seasonally (Carrasco et al., 1999; Benavente et al., 2005), but in this case the minimum values of $\mathrm{CO}_{2}$ are recorded during the autumn and winter and the maximum values 


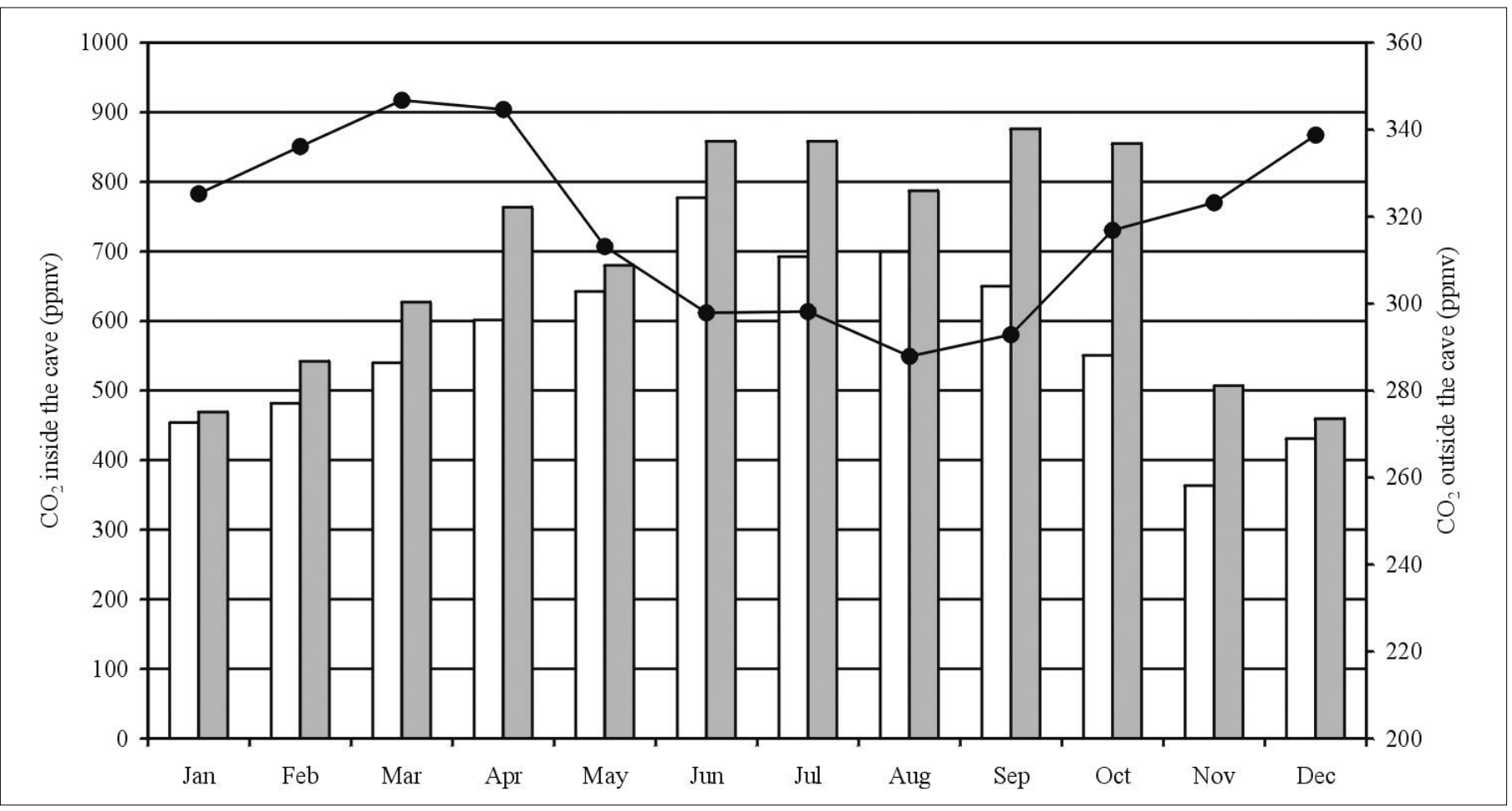

Fig. 2. Monthly $\mathrm{CO}_{2}$ concentrations averaged for last five years (2001-2005), outside the Nerja Cave (black line) and inside it, in $\mathrm{H}-\mathrm{B}$ (in white) and $\mathrm{H}-\mathrm{C}$ (in grey).

are recorded during the summer period (Fig. 2). During the autumn and winter, the mean monthly concentration of $\mathrm{CO}_{2}$ within the cave is around 525 ppmv while in the spring and summer; this value rises to 750 ppmv.

On an annual scale, the variations in $\mathrm{CO}_{2}$ content in the subterranean atmosphere are generally similar to those of the number of visits to the cave and to those of the air temperature, both outside and inside the cave. All these parameters fit an undulating curve, with maximums in the spring and summer and minimums in the autumn and winter (Fig. 3). In general, during the autumn, winter and spring, the exterior temperature is lower than that recorded inside the cave while, during the summer, the temperature outside the cave exceeds that recorded inside (Fig. 3). The greatest temperature difference between the exterior and interior of the cave is recorded between December and February and during the summer, from June to August.

If a further analysis is carried out, at a monthly scale, it is observed that during some months of the year the temporal evolution of the mean monthly $\mathrm{CO}_{2}$ concentration in the air inside the cave is identical to the exterior air temperature, meanwhile during other months it is clearly similar to the visitor number (Fig 4).

In order to determine the relation between the air temperature and the visitor number with respect to the $\mathrm{CO}_{2}$ content of the air inside the cave, for each of the months examined during the study, the following correlation diagrams were made: $\mathrm{CO}_{2}$ and external/ internal temperature difference, and $\mathrm{CO}_{2}$ and visitor number. Thus, the corresponding correlation coefficients were obtained (Table 1).

The correlation curves obtained (Fig. 5) and the coefficients shown in Table 1 reveal the following:

- A significant correlation between the $\mathrm{CO}_{2}$ content within the cave and the visitor number.

- A significant positive correlation between the $\mathrm{CO}_{2}$ content within the cave and the external/internal temperature difference between January and May (except in February) and from October to December, although during this month there was a clearer correlation with the visitor number.

- A significant negative correlation between the $\mathrm{CO}_{2}$ content inside the cave and the external/internal air temperature during some summer months (June to September).

- In some months characterised by high visitor numbers, such as May (monthly average of 52,000 visitors) the only correlation observed was between the $\mathrm{CO}_{2}$ content of the air and the external/internal air temperature difference.

- In months characterised by low visitor numbers, such as February (about 21,000 visitors on average) the only correlation observed was between the $\mathrm{CO}_{2}$ content within the cave and the visitor number.

\section{DISCUSSION}

The $\mathrm{CO}_{2}$ within caves is derived from different sources: (1) external atmosphere, (2) soil overlying the caves, where biological activity produces $\mathrm{CO}_{2}$ that is transported by water seeping through the soil and network of rock voids, (3) oxidation by bacteria of organic matter in carbonated rocks or cave deposits, (4) deep gas diffusion or transport and (5) human activity (the respiration of visitors within the cave).

The temporal variation in the $\mathrm{CO}_{2}$ content of the air outside the cave presents minimum values during the summer months, coinciding with maximum values of the external air temperature. This summer decrease 


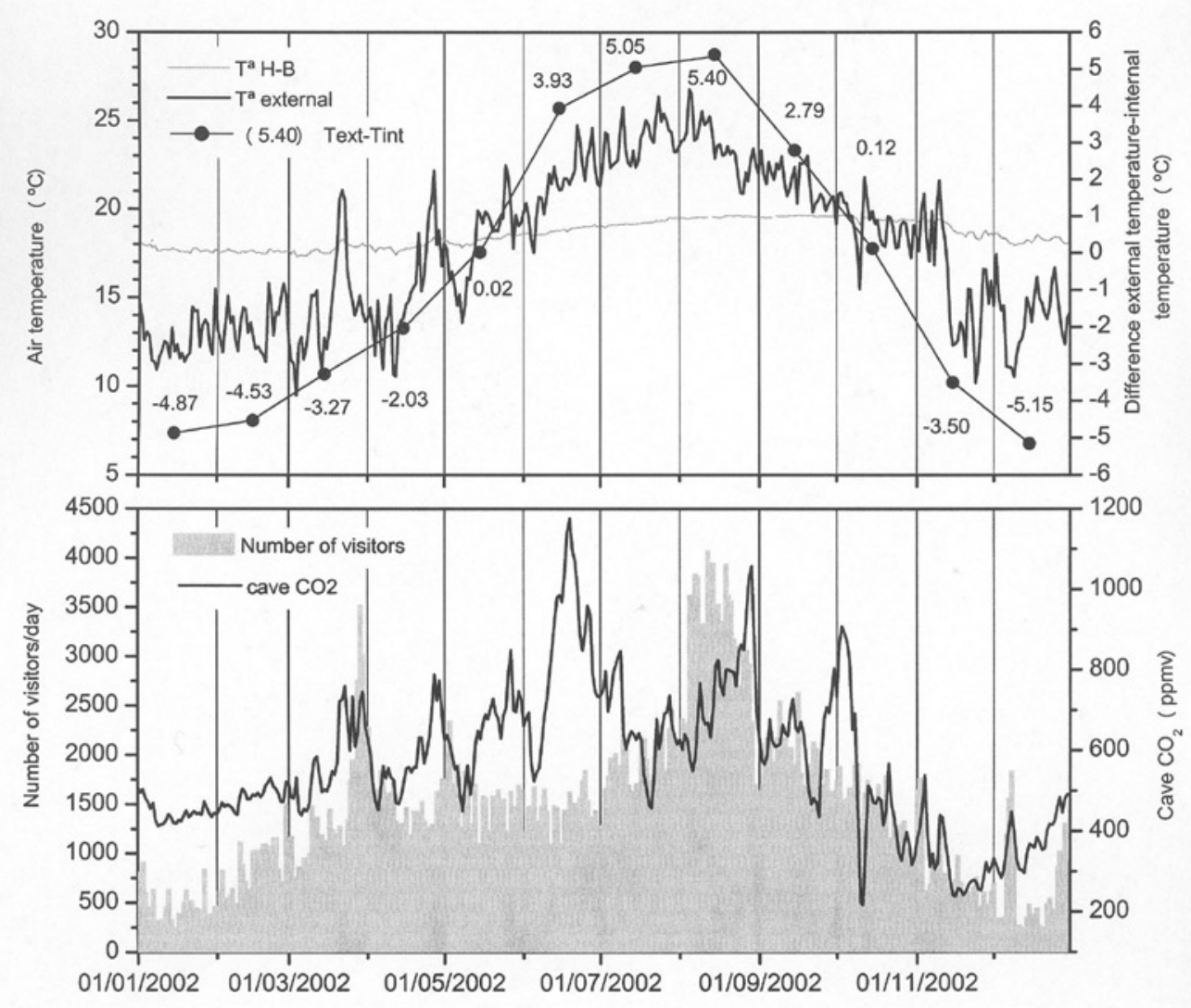

Fig. 3. Annual visitor number, $\mathrm{CO}_{2}$ concentration inside the cave (H-B), external and internal $(\mathrm{H}-\mathrm{B})$ air temperature during the year 2002, and monthly temperature differences averaged for last five years (2001-2005).
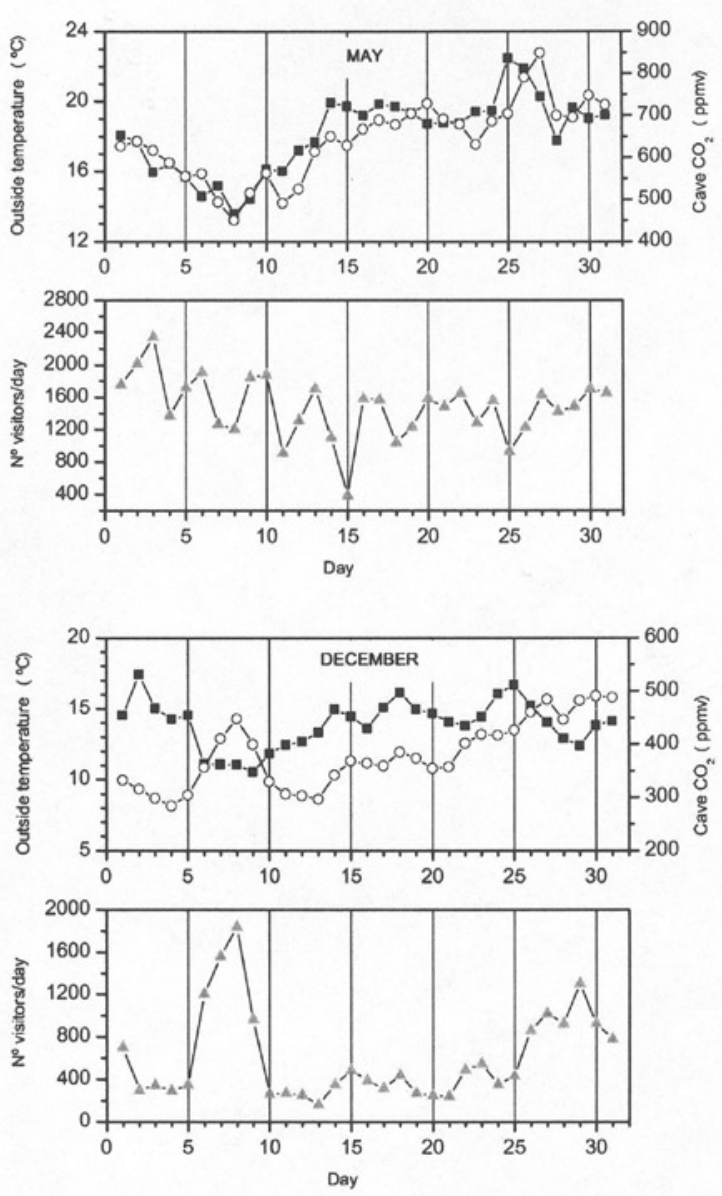

Fig. 4. Monthly variation in $\mathrm{CO}_{2}$ concentration in the air inside the cave (white marker), external air temperature (black marker) and visitor number (grey marker) during May and December 2002, respectively. in atmospheric $\mathrm{CO}_{2}$ must be related to the reduction in the plant cover of the immediate surroundings of the cave, as many species lose their leaves as a mechanism of adaptation to the very dry conditions normally encountered during this season (Batiot et al., 2003) and to the reduction in the plants' vital activities.

The correlation diagrams reveal the close relation, maintained practically throughout the year and irrespective of the visitor number, between the $\mathrm{CO}_{2}$ content of the air within the cave and the temperature difference between the exterior and the interior of the cave. This same relation has been described by other authors for the Altamira Cave (Villar et al., 1983). The temperature difference between the exterior and the interior of the cave influences the exchange of air and favours its natural ventilation.

The ventilation in the Nerja Cave was measured by means of a study of the concentration of radon inside the cave (Cañete, 1997; Dueñas et al., 1999). The seasonal variation in radon concentration within the cave is similar to that of the external air temperature, with minimum concentrations of radon being measured in the autumn and winter, and maximum concentrations during the spring and summer. These authors described a positive linear correlation between the concentration of radon in the air inside the cave and the external air temperature; therefore, there is an inverse linear correlation between the ventilation of the cave and the external temperature. In the Nerja Cave, during the autumn and winter, the ventilation is high 


\begin{tabular}{|c|c|c|c|c|c|c|c|c|c|c|}
\hline & \multicolumn{2}{|c|}{2001} & \multicolumn{2}{|c|}{2002} & \multicolumn{2}{|c|}{2003} & \multicolumn{2}{|c|}{2004} & \multicolumn{2}{|c|}{2005} \\
\hline & A & B & A & B & A & B & A & B & A & $\mathrm{B}$ \\
\hline January & 0,60 & 0,52 & - & 0,77 & 0,73 & 0,61 & - & 0,76 & & \\
\hline February & - & 0,46 & - & 0,82 & & & - & 0,56 & - & 0,66 \\
\hline March & 0,81 & - & 0,67 & 0,60 & & & 0,72 & 0,40 & 0,69 & 0,94 \\
\hline April & - & 0,42 & 0,78 & - & - & - & - & 0,88 & 0,82 & - \\
\hline May & 0,85 & - & 0,81 & - & 0,76 & - & 0,82 & - & 0,47 & - \\
\hline June & $-0,47$ & - & 0,58 & - & 0,56 & - & $-0,52$ & - & & \\
\hline July & - & - & - & - & $-0,76$ & - & $-0,71$ & - & $-0,70$ & - \\
\hline August & $-0,48$ & - & $-0,73$ & - & $-0,42$ & - & 0,37 & 0,79 & - & 0,69 \\
\hline September & - & 0,40 & - & - & - & - & $-0,67$ & - & - & - \\
\hline October & 0,71 & - & 0,54 & 0,43 & 0,76 & - & 0,66 & - & 0,58 & - \\
\hline November & 0,37 & - & 0,75 & - & - & - & 0,52 & - & 0,46 & - \\
\hline December & - & 0,64 & - & 0,73 & 0,48 & - & - & 0,89 & - & 0,91 \\
\hline
\end{tabular}

Table 1- Correlation coefficients between (A) $\mathrm{CO}_{2}$ inside the cave and external/internal temperature differences and (B) $\mathrm{CO}_{2}$ inside the cave and visitor number, during the period 2001-2005. The $\mathrm{CO}_{2}$ and internal air temperature data correspond to the Cascade Hall (H-B).
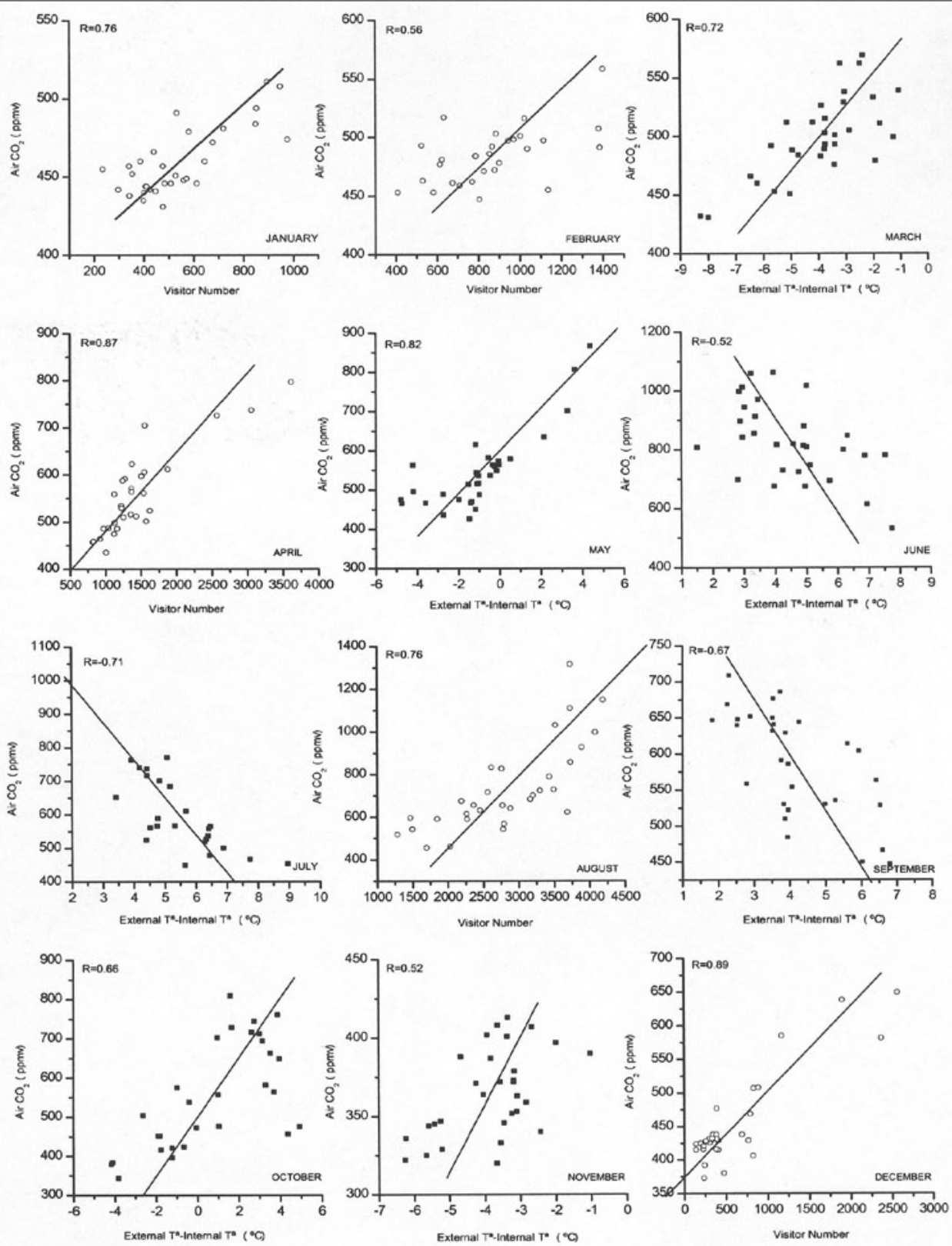

Fig. 5. Correlation diagrams made with daily data for $\mathrm{CO}_{2}$ within the cave, internal/external temperature differences and visitor number during 2004. $\mathrm{CO}_{2}$ and internal air temperature data correspond to the Cascade Hall (H-B). 
because the external air is colder and, therefore, more dense than that found within the cave, and so it enters the cave easily, displacing the internal air. During the spring and summer, the ventilation is low because the internal air is denser than the external air, and so air circulation is restricted or halted. This air circulation pattern would correspond to a "cold air trap" type of cave (Choppy, 1982; Buecher, 1999).

There is a positive correlation between the $\mathrm{CO}_{2}$ content and the difference between external and internal air temperatures during the autumn, winter and spring; that is, when this difference increases, the $\mathrm{CO}_{2}$ levels within the cave are higher. At first sight, this result seems contradictory, as a greater difference between the external and internal temperatures and the fact that the external temperature is lower than the internal one would mean a higher exchange of air, which would bring about a reduction in levels of $\mathrm{CO}_{2}$. The degree of ventilation is considered as being high and the atmospheric $\mathrm{CO}_{2}$ decreases sufficiently to enable the anthropogenic $\mathrm{CO}_{2}$ contribution to be observed which originates from the respiration of visitors. This would be the reason underlying the high correlation observed between the $\mathrm{CO}_{2}$ content of the air inside the cave and the visitor number in the winter months when visitor numbers are low, in December, January and February.

During summer, there is a negative correlation between $\mathrm{CO}_{2}$ and the temperature difference between the external and the internal air, and thus when the temperature difference increases, the $\mathrm{CO}_{2}$ content within the cave is lower. During this season, the air temperature is very similar in each of the cave's chambers, irrespective of their proximity to or distance from the entrance; furthermore, the external temperature is higher than the internal temperature, and so there are no convective-type movements of air masses and the renovation of the air is much slower, due to the lower ventilation (Cañete, 1997). During summer, a positive correlation between the $\mathrm{CO}_{2}$ concentration in the air in the cave and the visitor number can only be observed in August, which is the month that receives the most visits in the whole year averaging 100,000 visits/month.

Therefore, the main cause of the temporal variation of the $\mathrm{CO}_{2}$ content of the air of Nerja Cave must be the ventilation within the cave, that is, the exchange of air between the exterior and the interior of the cave, although the influence that other parameters may have on the evolution of the cave's $\mathrm{CO}_{2}$ concentration in the air is considered, such as the dripwater rate, whose temporal variation, similar to that of the interior air $\mathrm{CO}_{2}$, determinates a higher or lower contribution of biogenic $\mathrm{CO}_{2}$ to the cave's interior.

\section{CONCLUSIONS}

The mean annual $\mathrm{CO}_{2}$ content of the air outside the Nerja Cave was around $320 \pm 21$ ppmv during the study period (2001-2005). Analysis of the temporal variation of the $\mathrm{CO}_{2}$ content of the air revealed the existence of a timelag of around 3-4 months between the maximum and minimum values of $\mathrm{CO}_{2}$ measured outside and inside the cave.

The $\mathrm{CO}_{2}$ content within the Nerja Cave is fundamentally related to the natural ventilation within the cave, this being determined by the difference in temperature between the air outside and that inside the cave. During autumn, winter and spring, a positive correlation between the $\mathrm{CO}_{2}$ content of the air inside the cave and the temperature difference between the external and internal air was found, so that when this difference increased there was a higher level of $\mathrm{CO}_{2}$ within the cave. Then, the ventilation is high and $\mathrm{CO}_{2}$ levels are mainly of human origin.

During the summer, there was a negative correlation between $\mathrm{CO}_{2}$ and the temperature difference between the air inside and the air outside of the cave: when the temperature difference increases, the $\mathrm{CO}_{2}$ content within the cave is lower. At this time of the year, the renovation of the air is much slower due to the lower ventilation.

In future studies, an analysis of the ${ }^{13} \mathrm{C}$ content of air and water samples obtained within the cave would be highly useful in determining with greater precision the origin of the $\mathrm{CO}_{2}$ within the cave, as has been suggested by various authors (Clark \& Fritz, 1997, Batiot et al., 2006).

\section{ACKNOWLEDGMENTS}

This study is a contribution to Research Group RNM308 of Junta de Andalucía (Hydrogeology Group) and to Project 513 of the UNESCO PIGC.

\section{REFERENCES}

Atkinson T.C., 1977 - Carbon Dioxide in atmosphere of unsaturated zone- Important control of groundwater hardness in limestones. Journal of Hydrology, 35 (1-2): 111-123.

Baldini J.U.L., Baldini L.M., McDermott F. \& Clipson N., 2006 - Carbon dioxide sources, sinks, and spatial variability in shallow temperate zone caves: Evidence from Ballynamintra Cave, Ireland. Journal of Cave and Karst Studies, 68 (1): 4-11.

Batiot C., 2002 - Etude expérimentale du cycle du carbone en régions karstiques. Apport du carbone organique et du carbone minéral à la connaissance hydrogéologique des systèmes. Site expérimental de Vaucluse, Jura, Larzac, Région Nord-Montpelliéraine, Nerja (Espagne). Thèse de Doctorat, Univ. d'Avignon, 247 p.

Batiot C., Liñán C., Andreo B., Emblanch C., Carrasco F. \& Blavoux B., 2003 - Use of TOC as tracer of diffuse infiltration in a dolomitic karstic system: the Nerja Cave (Andalusia, southern Spain). Geophysical Research Letters, 30(22): 2179.

Batiot C., Seidel J.L., Jourde H., Hébrard O. \& BaillyComte V., 2006 - Seasonal variations of $\mathrm{CO}_{2}$ and Radon222 in a Mediterranean cave (causse d'Aumelas, SE France). In: Durán J.J., Andreo B. \& Carrasco F. (Eds.)- Karst, cambio climático y aguas subterráneas. Publicaciones del Instituto Geológico y Minero de España, serie: Hidrología y Aguas Subterráneas, 18: 369-375. 
Batiot-Guilhe C., Seidel J.L., Jourde H., Hérbrard O. \& Bailly-Comte V., 2007 - Seasonal variations of $\mathrm{CO}_{2}$ and ${ }^{222} \mathrm{Rn}$ in a Mediterranean sinkhole-spring (Causse d'Aumelas, SE France). International Journal of Speleology, 36(1): 51-56.

Benavente J., El-Mabrouki K., Molina J.L., Liñán C., Simón M.D. \& Carrasco F., 2005 - Variaciones espaciales y temporales en la concentración de $\mathrm{CO}_{2}$ en el interior de una cavidad turística (Cueva de Nerja, Málaga, España). In: Durán J.J. (Ed). Libro de resúmenes del primer Congreso Español sobre Cuevas Turisticas, Lekunberri (Navarra): 28.

Bourges F., Mangin A. \& D'Hulst D., 2001 - Le gaz carbonique dans la dynamique de l'atmosphère des cavités karstiques: l'exemple de l'Aven d'Orgnac (Ardèche). Comptes Rendus de l'Académie des Sciences de Paris, Sciences de la Terre et des Planètes, 333: 685-692.

Bourges F., Genthon P., Mangin A. \& D'Hulst D. 2006 Microclimates of L'Aven d'Orgnac and other French limestones caves (Chauvet, Esparros, Marsoulas). International Journal of Climatology, 26: 1651-1670.

Buecher R.H., 1999 - Microclimate study of Kartchner caverns, Arizona. Journal of Cave and Karst Studies, 61: 108-120.

Cañete S., 1997 - Concentraciones en Radón e intercambio de aire en la Cueva de Nerja. Tesis de Licenciatura, Univ. Málaga, 84 p.

Carrasco F., Andreo B., Benavente J. \& Vadillo I., 1995 Chemistry of the Nerja Cave system (Andalusia, Spain). Cave and Karst Science, 21 (2): 27-32.

Carrasco F., Andreo B., Durán J.J., Vadillo I. \& Liñán C., 1999 - Human influence on the karst water of the Nerja cave. In: Drew D. \& Hötzl H. (Eds.)- Human impacts and karst groundwater. International Contribution to Hydrogeology, 20: 168-173.

Carrasco F., Vadillo I., Liñán C., Andreo B. \& Durán J.J., 2002 - Control of environmental parameters for management and conservation of Nerja Cave (Malaga, Spain). Acta Carsológica, 31 (1): 105122.

Choppy J. 1982 - Dynamique de l'air. Phenomenes karstiques (1). Spéléo Club de Paris \& Club Alpin Français, Paris (France)

Clark I. \& Fritz P., 1997 - Tracing the carbon cycle. In: Environmental Isotopes in Hydrogeology, Lewis Publishers, $328 \mathrm{p}$.

Craven S.A., 1996 - Carbon Dioxide variations in Cango Cave, South Africa. Cave and Karst Science, 23(3): 89-92.

De Freitas C.R. \& Banbury K., 1999 - Build up and diffusion of carbon dioxide in cave air in relation to visitor numbers at the Glowworm Cave, New Zealand. In: Cave and karst management in Australasia XIII. Proceedings of the $13^{\text {th }}$ Australasian Conference on cave and karst management, South Australia. Australasian Cave and Karst Management: 84-89.

Denis A., Lastennet R., Huneau F. \& Malaurent P., 2005 - Identification of functional relationships between atmospheric pressure and $\mathrm{CO}_{2}$ in the cave of Lascaux using the concept of entropy of curves. Geophysical Research Letters, 32 (5) Art. No. L05810, 4p.
Dragovich D. \& Grose J., 1990 - Impact of tourism on carbon dioxide levels at Jenolan Caves, Australia: an examination of microclimatic constraints on tourist cave management. Geoforum, 21 (1): 111-120.

Dreybrodt W., 2000 - Equilibrium Chemistry of Karst Waters in Limestone Terranes. In: Klimchouk A.B., Ford D.C., Palmer A.N. \& Dreybrodt W. (Eds.), Speleogenesis, Evolution of Karst Aquifers, 126-135. Huntsville (Alabama, USA): National Speleological Society.

Dreybrodt W. \& Eisenlohr L., 2000 - Limestones Dissolution: Rates in Karst Environments. In: Klimchouk A.B., Ford D.C., Palmer A.N. \& Dreybrodt W. (Eds.), Speleogenesis, Evolution of Karst Aquifers, 136-148. Huntsville (Alabama, USA): National Speleological Society.

Dueñas C., Fernández M.C., Cañete S., Carretero J. \& Liger E., $1999-{ }^{222} R n$ concentrations, natural flow rate and the radiation exposure levels in the Nerja Cave. Atmospheric Environment, 33: 501-510.

Ek C. \& Gewelt M., 1985 - Carbon dioxide in cave atmospheres. New results in Belgium and comparision with some other countries. Earth Surface Processes and Landforms, 10: 173-187.

Ek C., 1968 - Teneur en $\mathrm{CO}_{2}$ de l'air de quelques grottes belges. Annales de Spéléologie, 23: 243-257.

Ek C., 1979 - Variations saisonnières des teneurs en $\mathrm{CO}_{2}$ d'une grotte belge: le Trou Money à Comblain-auPont. Annales de la Société Géologique de Belgique, 102: $71-75$.

Ek C., 1981 - Mesures du $\mathrm{CO}_{2}$ dans l'air des grottes: comparaison Québec-Belgique. In: International Union of Speleology (Ed.), $8^{\text {th }}$ International Congress of Speleology, Bowling Green (Kentucky), International Union of Speleology: 672-673.

Faimon J., Štelcl J. \& Sas D., 2006 - Anthropogenic $\mathrm{CO}_{2}$-flux into cave atmosphere and its environmental impact: A case study in the Císařská Cave (Moravian Karst, Czech Republic). Science of The Total Environment, 369(1-3): 231-245.

Fernández-Cortes A., Calaforra J.M. \& Sanchez-Martos F., 2006 - Spatiotemporal analysis of air conditions as a tool for the environmental management of a show cave (Cueva del Agua, Spain). Atmospheric Environment, 40(38): 7378-7394.

Halbert E.J.M., 1982 - Evaluation of carbon dioxide and oxygen data in atmosphere using the Gibbs Triangle and Cave Air Index. Helictite, 20(2): 6068.

Hoyos M., Soler V., Cañaveras J. C., SánchezMoral S. \& Sanz-Rubio E., 1998 - Microclimatic characterization of a karstic cave: human impact and microenvironmental parameters of a prehistoric rock art cave (Candamo cave, northern Spain). Environmental Geology, 33: 231-242.

James J.M., 1977 - Carbon dioxide in cave atmosphere. Transaction of British Cave Research Association, 4: 417-429.

Liang F., Song L. \& Wei X., 2000 - The influences of cave tourism on $\mathrm{CO}_{2}$ and temperature in Baiyun Cave, Hebei, China. International Journal of Speleology, 29 B (1/4): 77-87. 
Liñán C., Andreo, B., Carrasco F. \& Vadillo I., 2000 Consideraciones acerca de la influencia del $\mathrm{CO}_{2}$ en la hidroquimica de las aguas de goteo de la Cueva de Nerja (Provincia de Málaga). Geotemas, 1(3): 341-344.

Liñán C., Calaforra J.M., Cañaveras J.C., Carrasco F., Fernández Cortés A., Jiménez Sánchez M., Martín Rosales W., Sánchez Martos F., Soler V. \& Vadillo I., 2004 - Experiencias de monitorización medioambiental en cavidades turísticas. In: Andreo B. \& Durán J.J. (Eds). Investigaciones en sistemas kársticos españoles, Instituto Geológico y Minero de España, 385-429.

Renault P., 1968 - Sur la distinction de plusieurs régions karstiques en raison de la teneur en anhydride carbonique des atmosphères de grottes. C. R. Acad. Sci. Paris, 267: 2288-2290.

Spötl C. Fairchild I. \& Tooth A., 2005 - Cave air control on dripwater geochemistry, Obir Caves (Austria): Implications for speleothem deposition in dynamically ventilated caves. Geochimica et Cosmochimica Acta, 69(10), 2451-2468.

Troester J.M. \& White W.B., 1984 - Seasonal fluctuations in the carbon dioxide partial pressure in a cave atmosphere. Water Resources Research, 20: 153-156.
Villar E., Fernandez P.L., Gutierrez I., Quindós L.S. \& Soto J., 1986 - Influence of visitors on carbon concentrations in Altamira Cave. Cave Science, 13 (1): 21-23.

Villar E., Fernández P.L., Quindós L.S., Solana J.R. \& Soto J., 1983 - Flujos de materia en la Cueva de Altamira. In: Estudios fisico-químicos sobre la Cueva de Altamira, Ministerio de Cultura, Dirección General de Bellas Artes y Archivos, Monografia n ${ }^{\circ}$ 9: 45-66.

White W.B., 1988 - Geomorphology and Hydrology of Karst Terrains. Nueva York: Oxford University Press.

White W.B., 1997 - Thermodynamic equilibrium, kinetics, activation barriers, and reaction mechanisms for chemical reactions in the Karst Terrains. Environmental Geology, 30(1-2): 46-58.

Wood W.W. \& Petraitis M.J., 1984 - Origin and distribution of carbon dioxide in the unsaturated zone of the southern High Plains. Water Resources Research, 20: 1193-1208.

Wood W.W., 1985- Origin of caves and other solution openings in the unsaturated (vadose) zone of carbonate rocks: a model for $\mathrm{CO}_{2}$ generation. Geology, 13: 822-824.

Zelinka J., 2002 - Microclimatic research in the Slovakian show caves. Acta Carsologica, 31 (1): 151-163. 